\section{Seed Coating and Seeding Rate Effects on Turfgrass Germination and Establishment}

\author{
Bernd Leinauer ${ }^{1,3}$, Matteo Serena $^{1}$, and Devesh Singh ${ }^{2}$
}

AdDitional INDEX wORDs. polymer, reference evapotranspiration, subsurface drip irrigation, ZEBA

SumMary. A field experiment was conducted at New Mexico State University to investigate the effect of seeding rates and ZEBA polymer [starch-g-poly (2propenamide-co-propenoic acid) potassium salt] seed coating on the germination and establishment of warm- and cool-season grasses, and cool-season blends and mixtures. Grasses were established at recommended and reduced (50\% of recommended) seeding rates with coated and uncoated seeds under two irrigation regimes (98\% and 56\% reference evapotranspiration). With the exception of 'Bengal' creeping bentgrass (Agrostis stolonifera), the polymer coating did not improve germination of the turfgrasses tested 22 days after seeding (DAS). However, at the end of the establishment period (92 DAS), plots established with 'Bengal', Dunes Mix [mixture of 'Hardtop' hard fescue (Festuca longifolia), 'Baron' kentucky bluegrass (Poa pratensis), 'Barok' sheep fescue (Festuca ovina)], 'Panama' bermudagrass (Cynodon dactylon), and Turf Sense ${ }^{\mathrm{TM}}$ [mixture of 'Baronie' kentucky bluegrass, 'Barlennium' perennial ryegrass (Lolium perenne), and 'Barcampsia' tufted hairgrass (Deschampsia cespitosa)] achieved greater coverage (based on visual estimations) when coated seed was used compared with uncoated seed. Establishment was greater for 'Bengal', Dunes Mix, 'Panama', Turf Sense ${ }^{\mathrm{TM}}$, and Turf Saver ${ }^{\mathrm{TM}}$ [blend of 'Barlexas II', 'Barrington', and 'Labarinth' tall fescue (Festuca arundinacea)] when normal seeding rates were applied compared with reduced seeding rates. 'Barleria' crested hairgrass (Koelevia macrantba) plots did not establish, regardless of the treatments applied. Results showed that seed coating has the potential to improve establishment at recommended and reduced seeding rates and can compensate for less favorable conditions such as reduced irrigation, reduced seeding rate, or for a combination of both. At the end of the establishment period, not all grasses achieved coverage greater than $\mathbf{5 0 \%}$. Further research over a longer establishment period is needed to determine if coated seed can be beneficial in achieving full coverage.

S eeding is the most common establishment method used for turf areas (Christians, 1998). Seeding keeps establishment costs to a minimum (Burton, 1992) and is convenient because of the ease of transportation, storage, and spreading of seeds (Christians, 1998; Watschke and Schmidt, 1992). Seed coating was introduced by the vegetable industry in the late 1930s and early 1940s to increase seed size and

Financial support for the study was provided by Barenbrug USA, the Cooperative State Research, Education, and Extension Service, U.S. Department of Agriculture under Agreement Nos. 200534461-15661 and 2005-45049-03209, New Mexico State Water Resources Resource Institute, and New Mexico State University's Agricultural Experiment Station. We are also grateful for the support of New Mexico State University's Office for Facilities and Services.

We greatly appreciate R. Sallenave's help and assistance in preparing the manuscript.

${ }^{1}$ Department of Plant and Environmental Sciences, New Mexico State University, N230 Skeen Hall, Las Cruces, NM, 88003

${ }^{2}$ Barenbrug USA, West Coast Research Center, 36030 Tennessee Road, Albany, OR 97322

${ }^{3}$ Corresponding author. E-mail: leinauer@nmsu.edu. achieve seed uniformity (Kaufman, 1991; Roos and Moore, 1975). Seed coating has since evolved from simply changing seed size and shape to producing treated coatings to supply compounds that influence the microenvironment of each seed. Compounds can include fungicides, insecticides, herbicides, micro- and macronutrients, growth regulators, surfactants, and polymers, pesticides to protect from birds and rodents, and chemicals that stimulate or delay germination (Scott, 1989). The first published greenhouse study using coated turfgrass seed concluded that adhesives used to coat seed with limestone did not negatively impact kentucky bluegrass and tall fescue seedlings (Hathcock et al., 1984a). However, since then, the use of coated and treated seed in turfgrass establishment has given conflicting results. In a concurrent field study, Hathcock et al. (1984b) found that limestone in combination with various fertilizers as coating material improved germination or killed tall fescue or kentucky bluegrass seedlings, depending on the type of fertilizer coating. Berdahl and Barker (1980) tested five different wateradsorbent coatings on seed of russian wildrye (Elymus junceus) and found no effect on seed emergence over a wide range of soil matric potentials. Bruneau et al. (1989) investigated fertilizer-coated cool-season turf seed and found reduced germination in complete fertilizer-coated grass seed compared with grasses seeded with raw seed. The authors concluded that coated seed could not be recommended unless seeding rates were increased. However, Greipsson (1999) documented improved kentucky bluegrass establishment when seed coated with diatomaceous earth and cytokinins was used compared with uncoated seed or seed coated with diatomaceous earth only. To prevent seedling diseases, coatings treated with fungicides were introduced in late 1980s and early 1990s (Baldwin, 1993; Hummel, 1991). Hummel (1991) investigated seed coatings that included starter fertilizer and the fungicide metalaxyl at full and half seeding rates of creeping bentgrass and perennial ryegrass. He concluded that the coating increased establishment but could not compensate for the reduced seed density at half seeding rate. Conditions during the investigation did not allow for the evaluation of the fungicide treatment (Hummel, 1991). Research conducted by Newell (1997) and Newell et al. (1999) found increased establishment in kentucky bluegrass,

\begin{tabular}{lllc}
\hline $\begin{array}{l}\text { Units } \\
\text { To convert U.S. to SI, } \\
\text { multiply by }\end{array}$ & U.S. unit & SI unit & $\begin{array}{l}\text { To convert SI to U.S., } \\
\text { multiply by }\end{array}$ \\
\hline 0.3048 & $\mathrm{ft}$ & $\mathrm{m}$ & 3.2808 \\
0.0929 & $\mathrm{ft}^{2}$ & $\mathrm{~m}^{2}$ & 10.7639 \\
3.7854 & $\mathrm{gal}$ & $\mathrm{L}$ & 0.2642 \\
2.54 & inch $(\mathrm{es})$ & $\mathrm{cm}$ & 0.3937 \\
305.1517 & $\mathrm{oz} / \mathrm{ft}^{2}$ & $\mathrm{~g} \cdot \mathrm{m}^{-2}$ & 0.0033 \\
6.8948 & $\mathrm{psi}$ & $\mathrm{kPa}$ & 0.1450
\end{tabular}


perennial ryegrass, red fescue (Festuca rubra), and two seed mixtures when fungicide-coated seed was used and compared with controls. Most recently, Layton et al. (2007) investigated the effects of coating on warmseason seeded bermudagrass germination at six temperatures regimes. Seed coating of all five bermudagrasses did not increase germination compared with uncoated seed when germination was averaged across temperatures.

Since the introduction of seed coating, numerous coating materials have been suggested and tested, many of which are proprietary and unique to each seed company. Most recently, a new cornstarch coating by the name of ZEBA (Absorbent Technologies, Beaverton, OR) has been released and applied to warm- and cool-season turfgrass seeds (Arends, 2007). The coating consists of a polymer that exhibits water-retention capabilities of 400 times of its own weight (Absorbent Technologies, 2006; Arends, 2007). Currently, information is lacking on the effect of starch coating on germination and establishment of turfgrasses. Two studies were conducted at New Mexico State University, Las Cruces (U.S. Department of Agriculture Plant Hardiness Zone 8) to investigate the effect of ZEBA seed coating and seeding rates on the germination and establishment of cool-season turfgrasses, cool-season mixtures and blends, and bermudagrass when seeded in fall.

\section{Material and methods}

Field experiments were conducted at New Mexico State University from Sept. to Dec. 2006 to investigate the effect of seeding rates and ZEBA polymer seed coating on the germination and establishment of cool-season turfgrasses, cool-season blends and mixtures, and bermudagrass. The experimental design was a completely randomized block with turfgrasses, coating, and seeding rate as the main plot treatments (replicated four times) and day after seeding (DAS) as subplot treatments. The experiment was repeated at high irrigation $[98 \%$ reference evapotranspiration $\left.\left(\mathrm{ET}_{\mathrm{o}}\right)\right]$ and at moderate irrigation $\left(56 \% \mathrm{ET}_{\mathrm{o}}\right)$. Irrigation was applied through a subsurface drip system (DL2000 ${ }^{\mathrm{TM}}$; Toro, Riverside, CA) operated at $30 \mathrm{psi}$ and installed at a soil depth of $10 \mathrm{~cm}$. Drip lines were placed $30 \mathrm{~cm}$ apart from each other and pressure compensating emitters delivered water at a rate of $2 \mathrm{~L} \cdot \mathrm{h}^{-1}$. Subsurface drip irrigation was chosen because of the site's wind exposure that historically resulted in poor irrigation coverage from sprinkler systems. Irrigation amounts were calculated every Monday morning based on the previous week's cumulative $\mathrm{ET}_{\mathrm{o}}$ (Doorenbos and Pruitt, 1977). The 98\% $\mathrm{ET}_{\mathrm{o}}$ treatment received a daily equivalent of $14 \%$ of the total weekly $\mathrm{ET}_{\mathrm{o}}$, and the $56 \% \mathrm{ET}_{\mathrm{o}}$ treatment received $14 \%$ of the previous week's $\mathrm{ET}_{\mathrm{O}}$ every Monday, Wednesday, Friday, and Saturday. Visual inspection during the establishment period ensured that wetting fronts from drip irrigation lines reached the soil surface and moistened the soil uniformly. The soil at the site consisted of a sandy skeletal mixed thermic Typic Torriorthent, a sandy entisol typical for arid regions.

Grasses were seeded on 11 Sept. 2006 and a starter fertilizer (15N$6.5 \mathrm{P}-12.5 \mathrm{~K})$ was applied twice at a rate of $5 \mathrm{~g} \cdot \mathrm{m}^{-2}$ nitrogen during the course of the study. Plot size was $1 \times$ $1 \mathrm{~m}$. Grasses included 'Panama' bermudagrass, 'Bengal' creeping bentgrass, and 'Barleria' crested hairgrass. Furthermore, two cool-season blends, Turf Blue ${ }^{\mathrm{TM}}$ (kentucky bluegrass; Barenbrug USA, Tangent, OR) and Turf Saver ${ }^{\mathrm{TM}}$ (tall fescue; Barenbrug USA), and two cool-season mixtures, Dunes Mix and Turf Sense ${ }^{\mathrm{TM}}$ (2) (Barenbrug USA) were tested. The mixtures included 'Hardtop' hard fescue, 'Baron' kentucky bluegrass, and 'Barok' sheep fescue, and 'Baronie' kentucky bluegrass, 'Barlennium' perennial ryegrass, and 'Barcampsia' tufted hairgrass, respectively. Grasses, blends, and mixtures were seeded at recommended or reduced $50 \%$ of recommended) seeding rates, and seeding rates for coated grasses were increased to match seed number per plot of uncoated seed (Table 1).

Plots were assessed visually for seed germination on 21 Sept. 2006 (10 DAS) and on 3 Oct. (22 DAS) and for turfgrass coverage on 26 Oct. (45 DAS), 7 Nov. (57 DAS), 18 Nov. (68 DAS), 28 Nov. (78 DAS), and 12 Dec. (92 DAS). Germination ratings were taken across the entire plot on a scale of 0 to 3 with $0=$ no germination and $3=$ visible germination. A rating system that used a visual assessment of the entire plot rather than a seedling count was deemed appropriate because germination varied greatly among grasses and we were unable to choose a day that allowed for adequate seedling counts for all entries. When slower germinating grasses finally reached a countable mass, plots with faster germinating grasses had already reached a plant density that could no longer be counted. Turfgrass coverage was estimated using visual ratings that described the percentage coverage of the turfgrass' plots. A scatter plot of coverage versus DAS suggested a nonlinear relationship between the two variables. A sigmoidal association was identified to best describe establishment of the turf plots (GraphPad Prism 5.0 for Windows; GraphPad Software, La Jolla, CA). With this model, establishment begins at zero, increases first slowly, then rapidly, and progresses asymptotically toward a maximum cover, also called top plateau (Fig. 1). The model was subsequently used to calculate maximum cover and DAS to reach $50 \%$ cover for each treatment. Karcher et al. (2005a, 2005 b) used $50 \%$ coverage as a benchmark for turfgrass recovery from divot injury and this value was deemed appropriate to be applied to our study. Germination data, maximum cover, and DAS values were subjected to analysis of variance using SAS Proc Mixed (version 9.2; SAS Institute, Cary, NC) followed by multiple comparisons of means using Fisher's protected least significant difference test at the $0.05 \mathrm{P}$ level.

\section{Results and discussion}

Germination. The analysis of turfgrass germination revealed significant four-way interactions among irrigation, species, seeding rate, and DAS $(P=0.007)$, and significant twoway interaction between species and coating $(P=0.041)$. All other fourand all three-way interactions were not significant $(P>0.05)$. Therefore, germination means were pooled first over coating and are presented separately for each species, seeding rate, coating, and DAS for each irrigation treatment (Table 2). Second, germination means were pooled over irrigation, seeding rate, and DAS and are presented separately for each species and coating treatment (Table 3). 
Table 1. Turfgrass mixtures, blends, species, and varieties, and corresponding recommended seeding rates of all entries included in the study of seed coating and seeding rate effects on germination and stand establishment.

\begin{tabular}{|c|c|c|c|c|c|}
\hline \multirow[b]{2}{*}{ Mixture } & \multirow[b]{2}{*}{ Blend } & \multirow[b]{2}{*}{ Species } & \multirow[b]{2}{*}{ Variety } & \multicolumn{2}{|c|}{ Recommended seeding rate: uncoated } \\
\hline & & & & $\left(\mathrm{g} \cdot \mathrm{m}^{-2}\right)$ & $\left(\right.$ seeds $\left./ \mathrm{m}^{2}\right)$ \\
\hline & & Bermudagrass & Panama & 10 & 37,145 \\
\hline & & Creeping bentgrass & Bengal & 5 & 81,720 \\
\hline & & Crested hairgrass & Barleria & 10 & 34,050 \\
\hline & Turf Blue ${ }^{T M^{x}}$ & Kentucky bluegrass & Bariris $(25 \%)^{y}$ & 10 & 20,954 \\
\hline & & & Barrister $(40 \%)$ & & \\
\hline & Turf Saver ${ }^{\mathrm{TM}^{\mathrm{x}}}$ & Tall fescue & Barlexas II (30\%) & 30 & 10,753 \\
\hline & & & Barrington (30\%) & & \\
\hline & & & Labarinth $(40 \%)$ & & \\
\hline \multirow[t]{3}{*}{ Dunes Mix } & & Hard fescue & Hardtop $(70 \%)$ & 25 & 29,609 \\
\hline & & Kentucky bluegrass & Baron $(5 \%)$ & & \\
\hline & & Sheep fescue & Barok $(25 \%)$ & & \\
\hline
\end{tabular}

${ }^{\mathrm{z}} 1 \mathrm{~g} \cdot \mathrm{m}^{-2}=0.0033 \mathrm{oz} / \mathrm{ft}^{2}, \mathrm{l}$ seed $/ \mathrm{m}^{2}=0.0929 \mathrm{seed} / \mathrm{ft}^{2}$.

yercentage value listed next to variety name indicates the percentage by weight in mixture or blend.

xBarenbrug USA, Tangent, OR.

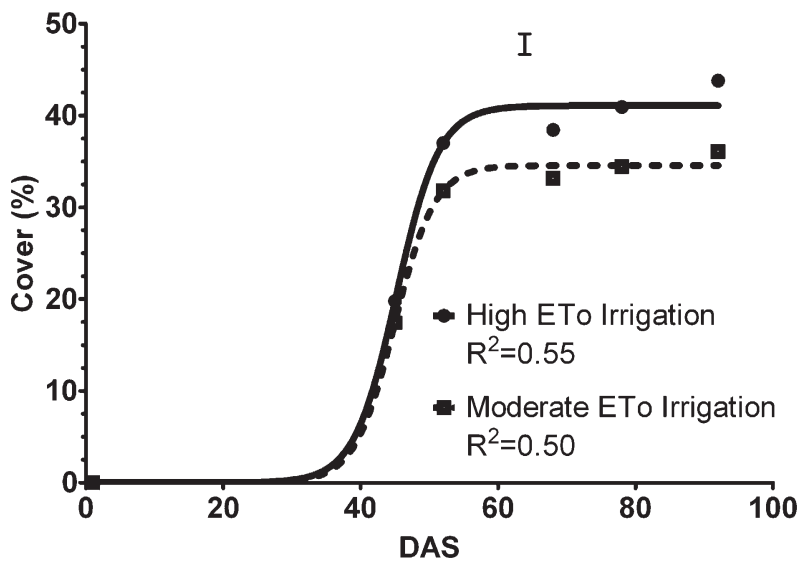

Fig. 1. Percentage turf cover under high [98\% reference evapotranspiration (ETo)] and moderate ( $56 \%$ ETo) irrigation as affected by days after seeding (DAS). Data were pooled over grasses 'Barleria' crested hairgrass, 'Bengal' creeping bentgrass, 'Panama' bermudagrass, Dunes Mix (mixture of 'Hardtop' hard fescue, 'Baron' kentucky bluegrass, and 'Barok' sheep fescue), Turf Sense ${ }^{\mathrm{TM}}$ (Barenbrug USA, Tangent, OR; mixture of 'Baronie' kentucky bluegrass, 'Barlennium' perennial ryegrass, and 'Barcampsia' tufted hairgrass), Turf Blue ${ }^{\mathrm{TM}}$ (Barenbrug USA; blend of 'Bariris', 'Barrister', 'Baron', and 'Barimpala' kentucky bluegrass), and Turf Saver ${ }^{\mathrm{TM}}$ (Barenbrug USA; blend of 'Barlexas II', 'Barrington', and 'Labarinth' tall fescue), seed treatment (coated and uncoated), and seeding rates [normal (according to rates recommended for uncoated seed by manufacturer) and $50 \%$ of normal rate]. Data points represent an average of 112 replicates. Error bar at the top plateau indicates a significant difference between the high $\mathrm{ET}_{\mathrm{o}}$ and the moderate $\mathrm{ET}_{\mathrm{o}}$ irrigation treatment via Fisher's protected least significant difference at $\alpha=0.05$.

'Barleria' and 'Panama' showed lowest germination among all tested grasses. Seeding rate and irrigation regime had no effect on their germination (Table 2). Normal seeding rates of 'Bengal' and Turf Saver ${ }^{\mathrm{TM}}$ resulted in highest germination rates under high and moderate irrigation (Table
2). Turf Saver ${ }^{\mathrm{TM}}$ also had the highest germination rates at reduced seeding rates on 10 and 22 DAS (Table 2). With the exception of Turf Sense ${ }^{\text {TM }}$ at high irrigation, all grasses showed lower germination at reduced seeding rates compared with normal seeding rates (Table 2 ). With the exception of
'Bengal', coating did not improve germination of the turfgrasses tested (Table 3).

Whether seed coating increases germination or not appears to be dependent on the type of coating. Fertilizer coating as used in previous studies (Bruneau et al., 1989; Hathcock et al., 1984b) improved or reduced germination. This can be explained by a high nutrient availability to the seedling, which impacts germination positively, or, due to a relatively high salt concentration in the coating surrounding the endosperm, negatively. Corn starch coating, however, which has little to no nutritional value, affects only seed water availability. Based on our findings, with the exception of 'Bengal', increased moisture alone was not sufficient to impact seed germination. Our findings concur with those of Berdahl and Barker (1980) who found no increased emergence of starch-coated russian wildrye seed compared with the uncoated control over several moisture ranges.

Establishment. The rate of establishment of the different turfgrasses was best described by the sigmoidal curve, yielding coefficients of determination $\left(\mathrm{R}^{2}\right)$ values ranging from 0.83 to 1.00 . Analysis of variance of maximum coverage data revealed significant species by moisture $(P=0.01)$ and species by seeding rate $(P=0.008)$ interactions and 
Table 2. Turfgrass germination ratings for high [ $98 \%$ reference evapotranspiration $\left.\left(\mathrm{ET}_{\mathrm{o}}\right)\right]$ and moderate $\left(56 \% \mathrm{ET}_{\mathrm{o}}\right)$ irrigation treatments at normal (recommended: uncoated) and reduced seeding rates (50\% of normal) and at 10 and $22 \mathrm{~d}$ after seeding (DAS) when data were pooled over seed treatments (coating).

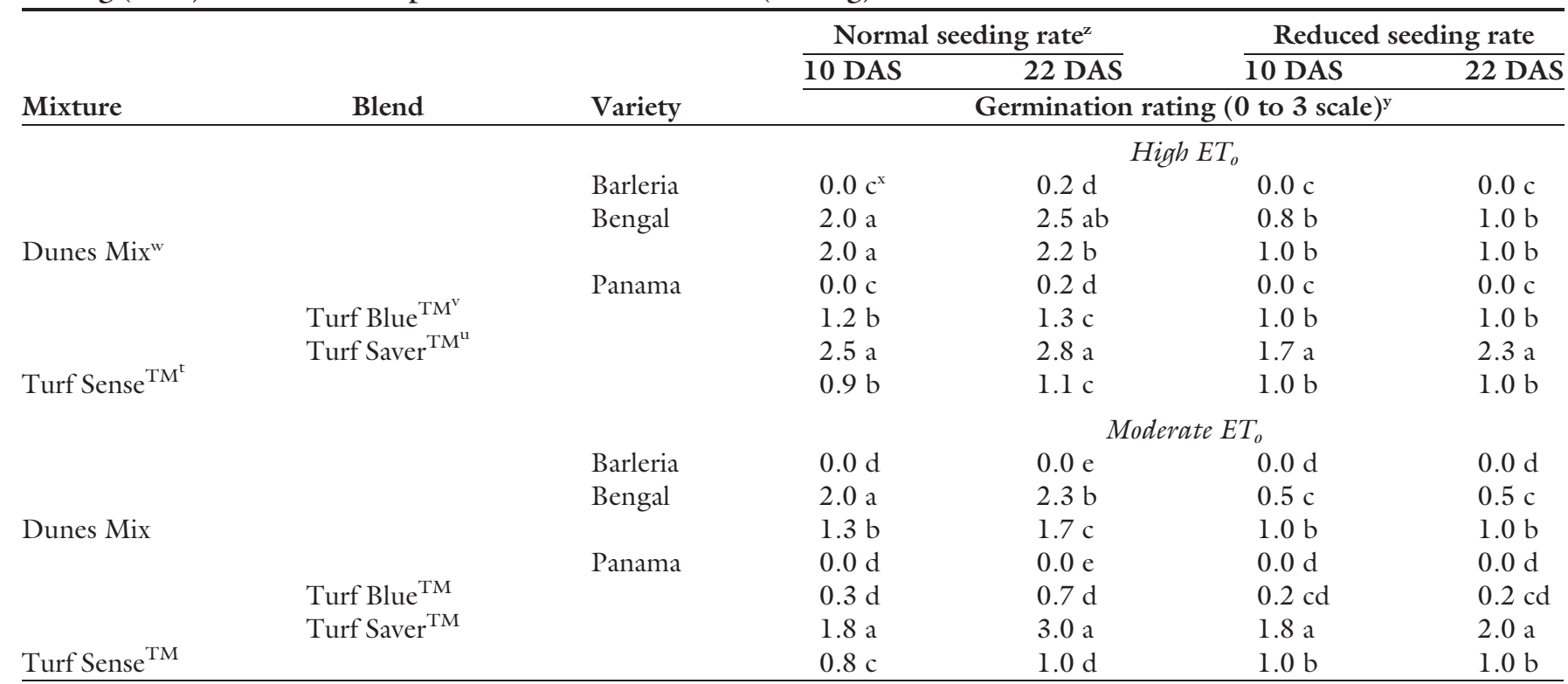

${ }^{2}$ The following normal seeding rates (according to rates recommended for uncoated seed by manufacturer) were applied: 'Barleria' crested hairgrass $10 \mathrm{~g} \cdot \mathrm{m}^{-2}$, 'Bengal' creeping bentgrass $5 \mathrm{~g} \cdot \mathrm{m}^{-2}$, Dunes Mix $25 \mathrm{~g} \cdot \mathrm{m}^{-2}$, 'Panama' bermudagrass $10 \mathrm{~g} \cdot \mathrm{m}^{-2}$, Turf Blue ${ }^{\mathrm{TM}} 10 \mathrm{~g} \cdot \mathrm{m}^{-2}$, Turf Saver ${ }^{\mathrm{TM}} 30 \mathrm{~g} \cdot \mathrm{m}^{-2}$, and Turf Sense $\mathrm{TM}^{\mathrm{TM}} 10 \mathrm{~g} \cdot \mathrm{m}^{-2}\left(1 \mathrm{~g} \cdot \mathrm{m}^{-2}=0.0033\right.$ $\left.\mathrm{oz} / \mathrm{ft}^{2}\right)$.

${ }^{\mathrm{y}} 0=$ no germination and $3=$ visible germination across the entire plot.

Values in columns (separately for each irrigation regime) followed by the same letter are not significantly different from one another via Fisher's protected least significant difference at $\alpha=0.05$.

"Mixture of 'Hardtop' hard fescue, 'Baron' kentucky bluegrass, and 'Barok' sheep fescue.

'Barenbrug USA, Tangent, OR; blend of 'Bariris', 'Barrister', 'Baron', and 'Barimpala' kentucky bluegrass.

"Barenbrug USA; blend of 'Barlexas II', 'Barrington', and 'Labarinth' tall fescue.

'Barenbrug USA; mixture of 'Baronie' kentucky bluegrass, 'Barlennium' perennial ryegrass, and 'Barcampsia' tufted hairgrass.

Table 3. Turfgrass germination ratings for coated and uncoated turfgrass seed when data were pooled over irrigation treatments $\{$ high $[98 \%$ reference evapotranspiration $\left(\mathrm{ET}_{\mathrm{o}}\right)$ ] and moderate $\left(56 \% \mathrm{ET}_{\mathrm{o}}\right)$ \}, seeding rates [normal (recommended: uncoated $^{\mathrm{z}}$ ) and reduced (50\% of normal)], and days after seeding (10 and $22 \mathrm{~d})$.

\begin{tabular}{|c|c|c|c|c|}
\hline \multirow[b]{3}{*}{ Mixture } & \multirow[b]{3}{*}{ Blend } & \multirow[b]{3}{*}{ Variety } & \multicolumn{2}{|c|}{ Seed treatment } \\
\hline & & & Coated & Uncoated \\
\hline & & & \multicolumn{2}{|c|}{ Germination rating $(0-3 \text { scale })^{y}$} \\
\hline \multirow{6}{*}{ Dunes $\mathrm{Mix}^{\mathrm{v}}$} & & Barleria & $0.0 \mathrm{~d}^{\mathrm{x}}$ & $0.0 \mathrm{e}$ \\
\hline & & Bengal & $1.7 \mathrm{bA}^{\mathrm{w}}$ & $1.2 \mathrm{bcB}$ \\
\hline & & & $1.5 \mathrm{~b}$ & $1.3 \mathrm{~b}$ \\
\hline & & Panama & $0.0 \mathrm{~d}$ & $0.0 \mathrm{e}$ \\
\hline & Turf Blue ${ }^{\mathrm{TM}^{\mathrm{u}}}$ & & $0.8 \mathrm{c}$ & $0.7 \mathrm{~d}$ \\
\hline & Turf Saver ${ }^{\mathrm{TM}}{ }^{\mathrm{t}}$ & & $2.2 \mathrm{a}$ & $2.3 \mathrm{a}$ \\
\hline Turf Sense ${ }^{\mathrm{TM}}$ & & & $0.9 \mathrm{c}$ & $1.0 \mathrm{c}$ \\
\hline
\end{tabular}

${ }^{2}$ The following normal seeding rates (according to rates recommended for uncoated seed by manufacturer) were applied: 'Barleria' crested hairgrass $10 \mathrm{~g} \cdot \mathrm{m}^{-2}$, 'Bengal' creeping bentgrass $5 \mathrm{~g} \cdot \mathrm{m}^{-2}$, Dunes Mix $25 \mathrm{~g} \cdot \mathrm{m}^{-2}$, 'Panama' bermudagrass $10 \mathrm{~g} \cdot \mathrm{m}^{-2}$, Turf Blue ${ }^{\mathrm{TM}} 10 \mathrm{~g} \cdot \mathrm{m}^{-2}$, Turf Saver ${ }^{\mathrm{TM}} 30 \mathrm{~g} \cdot \mathrm{m}^{-2}$, and Turf Sense $\mathrm{TM}^{\mathrm{TM}} 10 \mathrm{~g} \cdot \mathrm{m}^{-2}\left(1 \mathrm{~g} \cdot \mathrm{m}^{-2}=\right.$ $\left.0.0033 \mathrm{oz} / \mathrm{ft}^{2}\right)$.

${ }^{y} 0=$ no germination and $3=$ visible germination across the entire plot.

VValues in columns followed by the same lower case letter are not significantly different from one another via Fisher's protected least significant difference (LSD) at $\alpha=0.05$

"Values within one row followed by different upper case letters are significantly different from one another via LSD at $\alpha=0.05$.

'Mixture of 'Hardtop' hard fescue, 'Baron' kentucky bluegrass, and 'Barok' sheep fescue.

"Barenbrug USA, Tangent, OR; blend of 'Bariris', 'Barrister', 'Baron', and 'Barimpala' kentucky bluegrass.

'Barenbrug USA; blend of 'Barlexas II', 'Barrington', and 'Labarinth' tall fescue.

sBarenbrug USA; mixture of 'Baronie' kentucky bluegrass, 'Barlennium' perennial ryegrass, and 'Barcampsia' tufted hairgrass.

a significant moisture effect $(P<$ $0.0001)$. All other two-, three-, and four-way interactions were not significant $(P>0.05)$. When data were

pooled over all species, seeding rates, and coating treatments, plots established under moderate irrigation achieved lower maximum coverage
(36\%) compared with plots under high irrigation (45\%) (Fig. 1).

Plots established with coated seed of 'Bengal', Dunes Mix, 'Panama', and Turf Sense ${ }^{\mathrm{TM}}$ achieved greater coverage than those established with uncoated seed. Coating did not affect coverage of 'Barleria', Turf Blue ${ }^{\mathrm{TM}}$, or Turf Saver ${ }^{\mathrm{TM}}$ (Table 4). Seeding rate affected coverage on all plots except those of 'Barleria' (Table 4). Applying recommended seeding rates of 'Bengal', Dunes Mix, 'Panama', Turf Blue ${ }^{\mathrm{TM}}$, Turf Saver ${ }^{\mathrm{TM}}$, and Turf Sense ${ }^{\mathrm{TM}}$ resulted in significantly greater establishment and coverage than under reduced seeding rate. 'Barleria'seeded plots exhibited poor coverage, regardless of the treatments applied. Crested hairgrass has shown a history of germinating and establishing poorly because of seed dormancy issues (C. Arends, personal communication). Conditions necessary to break seed dormancy and achieve satisfactory establishment in this species have yet to be determined.

Several treatments included in this study did not reach $50 \%$ coverage by the end of the 3-month investigative period. Therefore, data were 
Table 4. Maximum turfgrass coverage (based on sigmoidal model estimates) for coated versus uncoated turfgrass species \{data pooled over high [ $98 \%$ reference evapotranspiration $\left.\left.\left(\mathrm{ET}_{\mathrm{o}}\right)\right]\right\}$ and moderate $\left(56 \% \mathrm{ET}_{\mathrm{o}}\right)$ irrigation and seeding rates [normal (recommended) ${ }^{\mathrm{z}}$ and reduced (50\% of normal rate)] and for species established at normal and reduced seeding rates [data pooled over high ETo and moderate ETo irrigation and over coating (coated and uncoated) treatments].

\begin{tabular}{|c|c|c|c|c|c|c|}
\hline \multirow[b]{3}{*}{ Mixture } & \multirow[b]{3}{*}{ Blend } & \multirow[b]{3}{*}{ Variety } & \multicolumn{2}{|c|}{ Seed treatment } & \multicolumn{2}{|c|}{ Seeding rate } \\
\hline & & & Coated & Uncoated & Normal & Reduced \\
\hline & & & \multicolumn{4}{|c|}{ Maximum coverage (\%) } \\
\hline \multirow{6}{*}{ Dunes $\mathrm{Mix}^{\mathrm{w}}$} & & Barleria & $15 \mathrm{f}^{\mathrm{y}}$ & $14 \mathrm{~d}$ & $17 \mathrm{f}$ & $12 \mathrm{~d}$ \\
\hline & & Bengal & $64 a A^{x}$ & $54 \mathrm{aB}$ & $70 \mathrm{aA}$ & $48 \mathrm{aB}$ \\
\hline & & & $57 \mathrm{bA}$ & $47 \mathrm{bB}$ & $61 \mathrm{bA}$ & $43 \mathrm{abB}$ \\
\hline & & Panama & $34 \mathrm{eA}$ & $15 \mathrm{~dB}$ & $31 \mathrm{eA}$ & $17 \mathrm{~dB}$ \\
\hline & Turf Blue $\mathrm{TM}^{\mathrm{T}}$ & & $48 \mathrm{c}$ & $43 \mathrm{~b}$ & $51 \mathrm{cA}$ & $41 \mathrm{bB}$ \\
\hline & Turf Saver ${ }^{\mathrm{TM}}{ }^{\mathrm{u}}$ & & $54 \mathrm{bc}$ & $47 \mathrm{~b}$ & $56 \mathrm{bcA}$ & $45 \mathrm{abB}$ \\
\hline Turf Sense $\mathrm{TM}^{\mathrm{T}}$ & & & $41 \mathrm{dA}$ & $31 \mathrm{cB}$ & $42 \mathrm{dA}$ & $30 \mathrm{cB}$ \\
\hline
\end{tabular}

${ }^{z}$ The following normal seeding rates (according to rates recommended for uncoated seed by manufacturer) were applied: 'Barleria' crested hairgrass $10 \mathrm{~g} \cdot \mathrm{m}^{-2}$, 'Bengal' creeping bentgrass $5 \mathrm{~g} \cdot \mathrm{m}^{-2}$, Dunes Mix $25 \mathrm{~g} \cdot \mathrm{m}^{-2}$, 'Panama' bermudagrass $10 \mathrm{~g} \cdot \mathrm{m}^{-2}$, Turf Blue $\mathrm{T}^{\mathrm{TM}} 10 \mathrm{~g} \cdot \mathrm{m}^{-2}$, Turf Saver ${ }^{\mathrm{TM}} 30 \mathrm{~g} \cdot \mathrm{m}^{-2}$, and Turf Sense ${ }^{\mathrm{TM}} 10 \mathrm{~g} \cdot \mathrm{m}^{-2}\left(1 \mathrm{~g} \cdot \mathrm{m}^{-2}=\right.$ $\left.0.0033 \mathrm{oz} / \mathrm{ft}^{2}\right)$.

Values in columns followed by the same lower case letter are not significantly different from one another via Fisher's protected least significant difference (LSD) at $\alpha=0.05$

"Values within one row (which consists of coated versus uncoated for seed treatment and normal versus reduced for seeding rate) followed by different upper case letters are significantly different from one another via LSD at $\alpha=0.05$. "Mixture of 'Hardtop' hard fescue, 'Baron' kentucky bluegrass, and 'Barok' sheep fescue.

'Barenbrug USA, Tangent, OR; blend of 'Bariris', 'Barrister', 'Baron', and 'Barimpala' kentucky bluegrass.

"Barenbrug USA, Tangent, OR; blend of 'Barlexas II', 'Barrington', and 'Labarinth' tall fescue.

'Barenbrug USA, Tangent, OR; mixture of 'Baronie' kentucky bluegrass, 'Barlennium' perennial ryegrass, and 'Barcampsia' tufted hairgrass.

analyzed separately for each irrigation treatment, coating treatment, and seeding rate. Table 5 lists DAS to reach $50 \%$ coverage separately for each species, seeding rate, irrigation, and coating. Most grasses achieved $50 \%$ coverage when coated seed was used at a normal seeding rate and high irrigation was applied. Turf Sense $\mathrm{T}^{\mathrm{TM}}$ was slowest to reach $50 \%$ compared with other grasses. 'Bengal' creeping bentgrass reached the $50 \%$ plateau with all treatment combinations except when uncoated seed was used at a reduced seeding rate under moderate irrigation. 'Bengal', Dunes Mix, and Turf Saver ${ }^{\mathrm{TM}}$ reached $50 \%$ coverage using coated seed at a reduced seeding rate under moderate irrigation. Days needed to reach $50 \%$ coverage differed among cool-season grasses only under high irrigation at normal seeding rates. Turf Sense ${ }^{\mathrm{TM}}$ was slowest to reach $50 \%$ when coated seed was used and Turf Saver ${ }^{\mathrm{TM}}$ was slowest when uncoated seed was used. Turf Sense $\mathrm{T}^{\mathrm{TM}}$ did not reach $50 \%$ coverage when uncoated seed was used (Table 5). As a group, cool-season grasses established best (as indicated by the number of grasses that reached $50 \%$ cover) when normal seeding rate and coated seed at high irrigation was applied.
Progressively fewer cool-season grasses reached $50 \%$ coverage as the number of suboptimum treatments (uncoated seed, reduced seeding rate, and moderate irrigation) increased (Table 5). Only 'Bengal' achieved $50 \%$ coverage at a reduced seeding rate using uncoated seed but high irrigation, and only Turf Saver ${ }^{\mathrm{TM}}$ reached $50 \%$ coverage at 109 DAS under the least favorable conditions (reduced seeding rate, uncoated seed, and moderate irrigation) (Table 5).

Our results indicate that seed coating can reduce the effect of less favorable conditions such as moderate irrigation, reduced seeding rate, or for a combination of both. 'Bengal', Dunes Mix, Turf Blue ${ }^{\mathrm{TM}}$, and Turf Saver $^{\mathrm{TM}}$ all achieved $50 \%$ coverage under high irrigation at normal seeding rate with uncoated seed and also at reduced seeding rate with coated seed. 'Bengal', Dunes Mix, and Turf Saver ${ }^{\mathrm{TM}}$ also reached $50 \%$ coverage under moderate irrigation at a reduced seeding rate with coated seed compared with normal seeding rate and uncoated seed. Furthermore, 'Bengal', Dunes Mix, and Turf Saver ${ }^{\mathrm{TM}}$ achieved 50\% coverage under moderate irrigation when coated seed was used and a reduced seeding rate was applied (Table 5).
'Barleria' crested hairgrass and 'Panama' bermudagrass did not reach $50 \%$ even under the most favorable conditions. 'Panama' reached 50\% coverage only under moderate irrigation when coated seed was applied at a normal seeding rate (Table 5). Delayed or poor establishment for 'Panama' can be explained by the fall seeding, when soil temperatures were not high enough for warm-season grasses to achieve active growth. Moderately irrigated root zones may have been warmer than highly irrigated root zones and subsequently promoted a more favorable soil environment for bermudagrass establishment. 'Barleria' has a documented history of establishing poorly because of lack of breaking seed dormancy (C. Arends, personal communication).

Our results indicate that higher seeding rates improved germination while ZEBA seed coating only had an effect on germination for 'Bengal' creeping bentgrass under reduced irrigation. However, seed coating had a significant effect on turfgrass establishment. At the end of the establishment period, four of the six coolseason grasses established better when coated seed was applied compared with uncoated seed. These results confirm those of Greipsson (1999) who also found increased establishment when seed coating was applied. At high irrigation and reduced seeding rate, four of the six cool-season grasses tested reached $50 \%$ coverage with coated seed compared with only one species when uncoated seed was used. Our results differ from those of Hummel (1991) who concluded that coating could not compensate for reducing the seeding rate by half. These differences can be explained by the different coating material (starter fertilizer and fungicide) that Hummel (1991) used in his study compared with the starch coating in our study. While starter fertilizer and fungicide treatment have no affect on moisture retention of the seed, the starch coating used in our study may have increased water availability to the seed, which consequently increased establishment rate.

Grasses did not fully establish by early Jan. 2007 because temperatures dropped below freezing and grasses turned dormant. Hall (1980) reported reduced root development and subsequent damage due to desiccation in 
Table 5. Days after seeding to reach $\mathbf{5 0 \%}$ coverage (based on sigmoidal model estimates) for coated versus uncoated turfgrass species under high [98\% reference evapotranspiration $\left.\left(\mathrm{ET}_{\mathrm{o}}\right)\right]$ and moderate irrigation $\left(56 \% \mathrm{ET}_{\mathrm{o}}\right)$ and at normal (recommended: uncoated $\left.^{\mathrm{z}}\right)$ and reduced $(50 \%$ of normal rate) seeding rates.

\begin{tabular}{|c|c|c|c|c|c|c|}
\hline \multirow[b]{3}{*}{ Mixture } & \multirow[b]{3}{*}{ Blend } & \multirow[b]{3}{*}{ Variety } & \multicolumn{2}{|c|}{ High $\mathrm{ET}_{\mathrm{o}}$ irrigation } & \multicolumn{2}{|c|}{ Moderate $\mathrm{ET}_{\mathrm{o}}$ irrigation } \\
\hline & & & Coated & Uncoated & Coated & Uncoated \\
\hline & & & \multicolumn{4}{|c|}{ Time after seeding to reach $50 \%$ coverage $(d)$} \\
\hline \multirow{4}{*}{ Dunes $\operatorname{Mix}^{\mathrm{x}}$} & \multirow{5}{*}{$\begin{array}{l}\text { Turf Blue }{ }^{\mathrm{TM}^{\mathrm{w}}} \\
\text { Turf Saver }^{\mathrm{TM}}\end{array}$} & Barleria & dnr & dnr & dnr & dnr \\
\hline & & Bengal & $53 \mathrm{~b}^{\mathrm{y}}$ & $56 \mathrm{~b}$ & $55 \mathrm{~b}$ & 64 \\
\hline & & & $53 \mathrm{~b}$ & $61 \mathrm{~b}$ & $54 \mathrm{~b}$ & 59 \\
\hline & & & $59 \mathrm{~b}$ & 66 a & $73 \mathrm{ab}$ & 57 \\
\hline \multirow[t]{2}{*}{ Turf Sense ${ }^{\mathrm{TM}}{ }^{\mathrm{u}}$} & & & $84 \mathrm{a}$ & dnr & dnr & dnr \\
\hline & & & \multicolumn{4}{|c|}{ Reduced seeding rate } \\
\hline \multirow{2}{*}{ Dunes Mix } & & Barleria & dnr & dnr & dnr & dnr \\
\hline & & Bengal & 60 & 68 & 71 & dnr \\
\hline Turf Sense ${ }^{\mathrm{TM}}$ & & & $\mathrm{dnr}$ & dnr & dnr & $\mathrm{dnr}$ \\
\hline
\end{tabular}

${ }^{2}$ The following normal seeding rates (according to rates recommended for uncoated seed by manufacturer) were applied: 'Barleria' crested hairgrass $10 \mathrm{~g} \cdot \mathrm{m}^{-2}$, 'Bengal' creeping bentgrass $5 \mathrm{~g} \cdot \mathrm{m}^{-2}$, Dunes Mix $25 \mathrm{~g} \cdot \mathrm{m}^{-2}$, 'Panama' bermudagrass $10 \mathrm{~g} \cdot \mathrm{m}^{-2}$, Turf Blue ${ }^{\mathrm{TM}} 10 \mathrm{~g} \cdot \mathrm{m}^{-2}$, Turf Saver ${ }^{\text {TM }} 30 \mathrm{~g} \cdot \mathrm{m}^{-2}$, and Turf Sense $\mathrm{TM}^{\mathrm{TM}} 10 \mathrm{~g} \cdot \mathrm{m}^{-2}\left(1 \mathrm{~g} \cdot \mathrm{m}^{-2}=0.0033\right.$ $\left.\mathrm{oz} / \mathrm{ft}^{2}\right)$.

'Values in columns followed by the same letter (separate for each seeding rate) are not significantly different from one another (Fisher's protected least significant difference, $\alpha=0.05)$.

'Mixture of 'Hardtop' hard fescue, 'Baron' kentucky bluegrass, and 'Barok' sheep fescue.

"Barenbrug USA, Tangent, OR; blend of 'Bariris', 'Barrister', 'Baron', and 'Barimpala' kentucky bluegrass.

'Barenbrug USA, Tangent, OR; blend of 'Barlexas II', 'Barrington', and 'Labarinth' tall fescue.

"Barenbrug USA, Tangent, OR; Mixture of 'Baronie' kentucky bluegrass, 'Barlennium' perennial ryegrass, and 'Barcampsia' tufted hairgrass

dnr: did not reach $50 \%$ coverage.

cool-season grasses that were established in the fall and went into dormancy prematurely. None of the treatments in this study reached full coverage by the end of the research period; however, coated grasses showed greater coverage and consequently greater maturity than uncoated grasses and would be less likely to be affected by desiccation and winter-kill. Further research over a longer establishment period is necessary to investigate if seed coating not only improves establishment to $50 \%$ coverage and compensates for a reduced seeding rate, but also to determine if establishing turf areas with coated seed can lead to irrigation water savings when full coverage needs to be achieved. In addition, research is needed to investigate whether coating increases the establishment of warmseason grasses when seeded at higher soil temperatures.

\section{Literature cited}

Absorbent Technologies. 2006. Material safety data sheet ZEBA. 21 July 2009. <http://www.zeba.com/pdfs/linked/ 20147_MSDS-All_Products.pdf>.
Arends, C. 2007. Innovations in turfgrass. TurfNews 30:98-99.

Baldwin, N.A. 1993. Seedling diseases. Sports Turf Bul. 182:9-10.

Berdahl, J.D. and R.E. Barker. 1980. Germination and emergence of russian wildrye seeds coated with hydrophilic materials. Agron. J. 72:1006-1008.

Bruneau, A.H., C.H. Peacock, and J.M. Di Paola. 1989. Cool season turfgrass establishment with fertilizer coated seed. Intl. Turfgrass Soc. Res. J. 6:263-265.

Burton, G.W. 1992. Breeding improved turfgrasses, p. 762-776. In: D.V. Waddington, R.N. Carrow, and R.C. Shearmann (eds.). Turfgrass. Amer. Soc. Agron., Crop Sci. Soc. Amer., Soil Sci. Soc. Amer., Madison, WI.

Christians, N. 1998. Fundamentals of turfgrass management. Ann Arbor Press, Chelsea, MI.

Doorenbos, J. and W.O. Pruitt. 1977. Crop water requirements. FAO Irr. Drainage Paper 24. Food and Agriculture Organization of the United Nations, Rome.

Greipsson, S. 1999. Seed coating improves establishment of surface seeded Poa pratensis used in revegetation. Seed Sci. Technol. 27:1029-1032.
Hall, J.R., III. 1980. Effect of cultural factors on tall fescue-kentucky bluegrass sod quality and botanical composition, $\mathrm{p}$. 367-378. In: J.B. Beard (ed.). Proc. 3rd Intl. Turfgrass Res. Conf., Munich, Germany. 11-13 July 1981. Intl. Turfgrass Soc., Amer. Soc. Agron., Crop Sci. Soc. Amer., Soil Sci. Soc. Amer., Madison, WI.

Hathcock, A.L., P.H. Dernoeden, J.J. Murray, and D.J. Wehner. 1984a. Seed germination of tall fescue and kentucky bluegrass as affected by adhesives. HortScience 19:442-443.

Hathcock, A.L., P.H. Dernoeden, T.R. Turner, and M.S. McIntosh. 1984b. Tall fescue and kentucky bluegrass response to fertilizer and lime seed coatings. Agron. J. 76:879-882.

Hummel, N.W., Jr. 1991. Coated seed. Grounds Maintenance 26:20, 22, 26.

Kaufman, G. 1991. Seed coating: A tool for stand establishment-A stimulus to seed quality. HortTechnology 1:98-102.

Karcher, D.E., M.D. Richardson, J.W. Landreth, and J.H. McCalla, Jr. 2005a. Recovery of bermudagrass varieties from divot injury. Appl. Turfgrass Sci. doi: 10.1094/ATS-2005-0117-01-RS.

Karcher, D.E., M.D. Richardson, J.W. Landreth, and J.H. McCalla, Jr. 2005b. 
Recovery of zoysiagrass varieties from divot injury. Appl. Turfgrass Sci. doi: 10.1094/ATS-2005-0728-01-RS.

Layton, J., G. Munshaw, B. Stewart, B. Baldwin, and H. Philley. 2007. Does seed coating affect bermudagrass germination? Amer. Soc. Agron., Crop Sci. Soc. Amer., Soil Sci. Soc. Amer. Annu. Mtg. p. 4. (Abstr.).

Newell, A.J. 1997. Effects of different seed treatments and coatings on the germination and establishment of four grass species. J. Sports Turf Res. Inst. 73:6772 .

Newell, A.J., J.C. Hart-Woods, and F.M.E. Crossley. 1999. Investigation of the effects of fortiva seed treatment on the establishment of different grass species and mixtures. J. Sports Turf Res. Inst. 75:89-99.

Roos, E.E. and F.D. Moore. 1975. Effect of seed coating on performance of lettuce seeds in greenhouse soil tests. J. Amer. Soc. Hort. Sci. 100:573-576.
Scott, J.M. 1989. Seed coatings and treatments and their effects on plant establishment. Adv. Agron. 42:43-83.

Watschke, T.L. and R.E. Schmidt. 1992. Ecological aspects of turf communities, p. 129-174. In: D.V. Waddington, R.N. Carrow, and R.C. Shearmann, (eds.). Turfgrass. Amer. Soc. Agron., Crop Sci. Soc. Amer., Soil Sci. Soc. Amer., Madison, WI. 